\title{
АКТИВНОСТИ ФЕРМЕНТОВ ПЕРОКСИДАЗЫ И ПОЛИФЕНОЛОКСИДАЗЫ ПОЧВ И ПОЧВЕННЫХ МИКРОМИЦЕТОВ СЕВЕРО-ВОСТОЧНОЙ ЧАСТИ \\ ACTIVITIES OF PEROXIDASE \\ АЗЕРБАЙДЖАНА
} AND POLYPHENOLOXIDASE ENZYMES SOIL AND SOIL MICROMYCETES OF NORTH-EASTERN PART OF AZERBAIJAN

V. Isayeva

Summary. Activity of peroxsidase and polyphenoloxidase of the soils in North-East part of Azerbaijan have been studied. The relation of these ferment activities to the content of humus in soils has been shown: a direct one- for polyphenoloxidase and an inverse one-for peroxidase. From the studied soils of Azerbaijan were isolated and tested more 200 fungal strains belonging to the following genera: Rhizopus, Mucor, Aspergillus, Penicillium, Geotrichum, Cephalosporium, Fusarium, Trichoderma, Verticillium, Alternaria, Cladosporium. From the 8 active strains, most strains were representatives of the genera Fusarium, Cladosporium, Penicillium. Along with the isolated strains of fungi, the activity of oxidoreductases was exhibited by museum strains of predatory fungi of the genera Arthrobotrys and Nematophagus.

Keywords: enzyme activity, peroxsidase, poliphenoloxidase, humus, micromycetes, predatory fungi.

\author{
Исаева Вусаля Камаледдин кызы \\ М.н.С., Институт Микробиологии НАН \\ Азербайджана, г. Баку, ababayevairada@mail.ru
}

Аннотация. В статье изучена пероксидазная и полифенолоксидазная активности почв Северо-Восточной части Азербайджана. В исследованных почвенных образцах между содержанием в них гумуса и активностью полифенолоксидазы наблюдается прямая, в отношении же активности пероксидазы - обратная зависимость. Из исследованных почв Азербайджана было выделено и испытано более 200 штаммов плесневых грибов, относящихся к следующим родам: Rhizopus, Mucor, Geotrichum, Aspergillus, Penicillium, Fusarium, Trichoderma, Verticillium, Alternaria, Cladosporium. Из числа 8 активных большинство штаммов оказались представителями родов Aspergillus, Fusarium, Penicillium. Наряду с выделенными штаммами грибов активность оксидоредуктаз проявляли музейные штаммы хищных грибов родов Arthrobotrys и Nematophagus.

Ключевые слова: ферментативная активность, пероксидаза, полифенолоксидаза, гумус, микромицеты, хищные грибы.

некоторых гетероциклических соединений) за счет кислорода перекиси водорода и других органических перекисей, образующихся в результате жизнедеятельности микроорганизмов [13]. В связи с этим, в последние годы в биохимических исследованиях почв определенное внимание уделялось изучению активности ПО и ПФО. В ряде работ активность этих ферментов изучалась и интерпретировалась в связи с общей биологической активностью различных типов почв $[1,2,8,11]$ с содержанием гумуса в почвах [14,15], изменением активности данных ферментов при внесении растительных остатков и удобрений [5] и т.д.

Микроскопические грибы как продуценты ПО и ПФО изучены недостаточно, но именно они являются максимально пригодными для использования ферментов в производстве, так как уже зарекомендовали себя как надежные и экономически выгодные продуценты многих БАВ и ферментов, в частности. Изучение ферментных систем грибов способствует выяснению их физиологи- 
Таблица 1. Содержание гумуса и активность ферментов в почвах северо-восточной части Азербайджана в весенний сезон

\begin{tabular}{|l|l|l|l|l|}
\multirow{2}{*}{ Типы почв } & \multirow{2}{*}{ Гумус, } & \multicolumn{2}{|l|}{ Активность пурпургаллина, мг } & \multirow{2}{*}{ K,\% } \\
\cline { 3 - 5 } & & полифенолоксидаза & пероксидаза & \\
\hline Песчаная & 0,5 & 0,30 & 3,5 & 8,6 \\
\hline Серо-бурая & 1 & 0,40 & 3,2 & 12,5 \\
\hline Серая & 1,6 & 0,55 & 3,0 & 18,3 \\
\hline Светло-коричневая & 2,3 & 0,60 & 2,5 & 24 \\
\hline Лугово-степная & 2,7 & 0,70 & 2,1 & 0,33 \\
\hline Каштановая & 3,0 & 0,74 & 1,8 & 41,1 \\
\hline Лугово-коричневая & 3,5 & 0,86 & 2,0 & 57,3 \\
\hline Лугово-лесная & 3,8 & 0,92 & 46,0 \\
\hline
\end{tabular}

Примечание: К- коэффициент накопления гумуса

ческих особенностей и открывает возможности обнаружения новых видов и штаммов, которые могут найти применение в промышленности $[9,16]$.

Кроме того, исследование оксидоредуктаз, особенно фенолоксидазы и пероксидазы микроскопических грибов представляет интерес в связи со значительной ролью этих ферментов в биодеградации лигнина, детоксикации ксенобиотиков, межорганизменных взаимодействиях, а также в морфогенезе микромицетов $[4,17,18,19]$.

Задачей исследования было изучение активности ферментов ПО и ПФО в различных типах почвы северо-восточной части Азербайджана, а также выделение из исследуемых почв микромицетов и изучение их способности к образованию ПО и ПФО и отбор наиболее активных штаммов.

\section{Материалы и метолы}

Объектами исследования служили 8 образцов почв северо-восточной части Азербайджана, включая песчаную, серо-бурую, серую, светло-коричневую, темно- коричневую, каштановую и темно-каштановую, лугово-коричневая, лугово-лесная.

Активность полифенолоксидазы и пероксидазы определяли по методике Хазиева Ф.Х. [12]. Активность ферментов выражали в мг пурпургаллина на 1 гр. воздушно-сухой почвы.

Для характеристики динамики накопления гумуса в почвах использовали коэффициент накопления гумуса (К), предложенной Чундеровой А.И. (14), который определяет отношение активности ПФ к активности ПО, выраженной в процентах по формуле:

$$
K=\frac{S \cdot 100}{D} \%,
$$

где S- активность полифенолоксидазы, D- активность пероксидазы.

Для выделения микромицетов из почв использовали общепринятую методику [3]. Определение микромицетов проводили по соответствующим определителям [6]). Для определения пероксидазной активности чистые культуры микромицетов высевались на модифицированную морковную среду. Активность фермента в культуральной жидкости определяли в динамике с 5-й по 20-й день культивирования с интервалами в 5 дней о-толидиновым методом Лукомской И.С., Городецкого В.К. в модификации [10]. Каталазу определяли по Билай В.И. [7].

\section{Результаты и обсужАения}

Исследование 8 образцов почв (песчаная, серо-бурая, серая, светло-коричневая, темно- коричневая, каштановая и темно-каштановая, лугово-коричневая, лугово-лесная) северо-восточной части Азербайджана, показало на различную степень активности в них ферментов полифенолоксидазы, пероксидазы. Как видно из приведенных результатов (таб.1,2), при увеличении содержания гумуса в почве активность пероксидазы уменьшается, а степень активности фермента полифенолоксидазы, наоборот, увеличивается. Данные таблицы 1, показывают, что при минимальном содержании гумуса (0,5\%) в почвах летних образцов пероксидазная активность была максимальной (3,5 мг пурпургаллина). В лугово-лесных почвах содержание гумуса было максимальным и составило 3,8\%, тогда как активность пероксидазы уменьшилась, а активность полифенолоксидазы здесь увеличилась. Полученные данные свидетельствуют о том, что с увеличением плодородия почвы и содержания в ней гумуса активность пероксидазы снижается. В исследованных образцах почв наблюдается обратная зависимость между активностью этого фермента и активностью фермента полифенолоксидазы. 
Таблица 2. Содержание гумуса и активность ферментов в почвах северо-восточной части

Азербайджана в зимний сезон

\begin{tabular}{|l|l|l|l|l|}
\multirow{2}{*}{ Типы почв } & \multirow{3}{*}{ Гумус, } & \multicolumn{2}{|l|}{ Активность пурпургаллина, мг } & \multirow{2}{*}{ K,\% } \\
\cline { 3 - 6 } & & полифенолоксидаза & пероксидаза & \\
\hline Песчаная & 0,3 & 0,18 & 2,9 & 6,23 \\
\hline Серо-бурая & 0,8 & 0,32 & 2,4 & 13,3 \\
\hline Серая & 1,2 & 0,44 & 2,1 & 20,9 \\
\hline Светло-коричневая & 2,0 & 0,50 & 1,7 & 29,4 \\
\hline Лугово-степная & 2,2 & 0,55 & 1,1 & 39,3 \\
\hline Каштановая & 2,7 & 0,70 & 0,7 & 63,64 \\
\hline Лугово-коричневая & 3,0 & 0,72 & 0,5 & 102,8 \\
\hline Лугово-лесная & 3,3 & 0,80 & 160 \\
\hline
\end{tabular}

Таблица 3. Активность оксидоредуктаз микромицетов почв северо-восточной части Азербайджана

\begin{tabular}{|c|c|c|c|c|}
\hline Род & Число штаммов & Пероксидаза & Полифенолоксидаза & Каталаза \\
\hline Penicillium & 33 & 3 & 2 & 10 \\
\hline Aspergillus & 22 & - & 1 & 8 \\
\hline Fusarium & 21 & 2 & 1 & 6 \\
\hline Mucor & 17 & - & - & 4 \\
\hline Rhisopus & 22 & - & - & 6 \\
\hline Geotrichum & 24 & 1 & - & 5 \\
\hline Alternaria & 16 & 1 & - & 3 \\
\hline Verticillium & 22 & - & - & 7 \\
\hline Trichoderma & 20 & 1 & 2 & 6 \\
\hline Cladosporium & 15 & 1 & - & 4 \\
\hline Arthrobotrys & 35 & 3 & 2 & 8 \\
\hline Nematophagus & 22 & 1 & 1 & 7 \\
\hline Dactylella & 14 & - & - & 5 \\
\hline Candelabrella & 18 & 1 & - & 6 \\
\hline Golovinia & 15 & - & - & 4 \\
\hline
\end{tabular}

Такой характер связи между этими ферментами находит отражение в ряде исследовательских работ [14,15].

Аналогичная закономерность проявлялась и в результатах, полученных при исследовании образцов данных типов почв в зимний период. Однако, при сравнении показателей гумуса и активности изучаемых ферментов наблюдаются некоторые различия (таб.№ 2). Так, содержание гумуса и уровень активности ферментов пероксидазы и полифенолосидазы в зимний период несколько ниже, чем в весеннее время. Очевидно, это объясняется тем, что в конце вегетационного периода в почве создаются благоприятные условия для биологических процессов. Поступающие в почву в весенний период растительные остатки гумифицируются в бла- гоприятных аэробных условиях, в результате чего наблюдается некоторое повышение активности данных ферментов.

Из образцов исследованных типов почв было выделено более 200 штаммов микромицетов, относящихся к следующим 10 родам: Penicillium, Aspergillus, Fusarium, Mucor, Rhisopus, Geotrichum, Alternaria, Verticillium, Trichoderma, Cladosporium. У выделенных штаммов микромицетов изучалась способность продуцировать ПО, ПФО и каталазу. С этой целью выделенные грибы культивировали на питательной среде с отваром моркови и дубовой коры, которая по литературным данным является наиболее эффективной для продуцентов пероксидазы (10). Полученные данные представлены в таблице № 3. 
Как следует из таблицы, из общего числа 212 выделенных почвенных штаммов грибов, ПО была обнаружена у 8, ПФО- у 6, каталаза - у 59 штаммов.

В числе 8 штаммов, образующих ПО были следующие: 3- из рода Penicillium, 2- Fusarium, по одному штамму из рода Alternaria, Trichoderma, Cladosporium; активность ПФО была выявлена у грибов родов Penicillium, Fusarium, Aspergillus и Trichoderma. Каталазную активность проявляли все испытанные штаммы микромицетов.

Наряду с выделенными почвенными микромицетами была изучена активность изучаемых ферментов у 104 музейных щтаммов хищных грибов следующих родов: Arthrobotrys, Golovinia, Candelabrella, Dactylella, Nematophagus (таб.№ 3). Способность к выделению ПО в культуральную жидкость обнаружена только у 5 штам- мов хищных грибов и у 3 штаммов - была выявлена полифенолоксидазная активность. Каталазная активность, как и в случае с выделенными штаммами, обнаружена у всех музейных штаммов хищных грибов. Из числа 8 активных большинство являются представителями родов Arthrobotrys и Nematophagus.

Таким образом, полученные данные подтверждают связь между содержанием гумуса и активностью пероксидазы и полифенолоксидазы в почве, которая может служить одним из показателей направленности превращения гумусовых веществ почвы и наряду с агрохимическими показателями использоваться в качестве индикатора плодородия почв; отобранные в результате скрининга среди почвенных и музейных штаммов микромицетов наиболее активные продуценты данных ферментов являются перспективными для дальнейших исследований.

\section{ЛИТЕРАТУРА}

1. Алексеева А.А, Фомина Н. В. Ферментативная активность почв питомников лесостепной зоны Красноярского края // Вестник КрасГАУ, 2014, № 12, с. 70-75.

2. Боер И.В., Борцова И. Ю. Состояние почвенного микробоценоза как показатель экологического состояния антропогенно преобразованных почв // https:// studylib.ru/doc/3888009/boer-i.v. — borcova-i.yu.-sostoyanie-pochvennogo-mikrobiocenoza.

3. Егоров Н.С. Практикум по микробиологии. М., 1976, 307 с.

4. Колесникова И.Я., Труфанов А. М. Экологическая роль почвенных микромицетов в изменении биохимических показателей плодородия // Вестник АПК Верхневолжья, 2017, № 2 (38), с. 19-25.

5. Колесникова М. В. Активность ферментов полифенолоксидазы и пероксидазы под влиянием совместной запашки соломы озимой пшеницы и штамма Humicola fuscoatra ВНИсС 016 // Научный альманах, 2018, № 4-3 (42), с. 200-204.

6. Литвинов М. А. Определитель микроскопических грибов. Л.: Наука, 1967, 303 с.

7. Билай В. И. Методы экспериментальной микологии. К.: Наук. Думка, 1982, 550 с.

8. Михайловская Н. А., Черныш А. Ф., Погирницкая Т. В., Юхновец А. В. Ферментативная активность эродированных дерново-подзолистых почв на мощных моренных суглинках // Почвоведение и агрохимия, 2013, № 2(51), с. 123-132.

9. Негребецкая Э. Н. Гифомицеты лесной подстилки в чистых березовых насаждениях и их пероксидазная активность // http://www.potopalsky.kiev.ua/docs/ materiali\%20forumu/ozdorovlennia/23.doc.

10. Пидопличко Н. М., Борисова В. Н., Элланская И. А. 0 пероксидазе у микромицетов. Экспериментальная микология. К.: Наук. думка, 1968, с. $56-64$.

11. Порохина Е. В., Голубина О. А. Ферментативная активность в торфяных залежах болота Таган // Вестник ТГПУ (TSPU Bulletin), 2012,7 (122), с. $171-176$.

12. Хазиев Ф. Х. Методы почвенной энзимологии. М.: Наука, 1990, 189 с.

13. Хазиев Ф.Х. Системный экологичекий анализ ферментативной активности почв. М.: Наука, 1990, 202 с.

14. Чундерова А. И. Активность полифенолоксидазы и пероксидазы в дерново-подзолистых почвах. // Почвоведение, № 7, 1970, с. $22-28$.

15. Чундерова А. И. Ферментативная активность дерново-подзолистых почв Северо-Западной зоны: автореф. дис. д-ра биол. Наук. Таллин, $1973 .-46$ с.

16. Jakovljević V. D., Vrvić M. M. Potential of pure and mixed cultures of Cladosporium cladosporioides and Geotrichum candidum for application in bioremediation and detergent industry. Saudi J. Biol. Sci., 2018, 25(3): 529-536 (doi: 10.1016/j.sjbs.2016.01.020).

17. Kadri T., Rouissi T., Brar S. K., Cledon M., Sarma S., Verma M. Biodegradation of polycyclic aromatic hydrocarbons (PAHs) by fungal enzymes: A review. J. Environ. Sci., 2017, 51(1): 52-74 (doi: 10.1016/j.jes.2016.08.023).

18. Kwiatos N., Ryngajłło M., BieleckiS. Diversity oflaccase-coding genes in Fusarium oxysporum genomes. Front. Microbiol., 2015,6:33 (doi: 10.3389/fmicb.2015.00933).

19. Obruca S., Marova I., Matouskova P., Haronikova A., Lichnova A. Production of lignocellulosedegrading enzymes employing Fusarium solani F-552. Folia Microbiol., 2012, 57(3): 221-227 (doi: 10.1007/s12223-012-0098-5). 